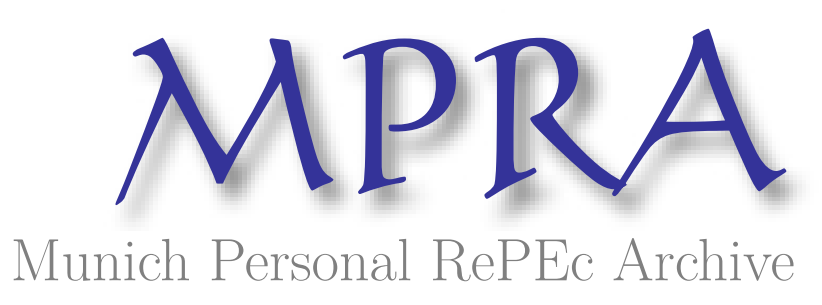

\title{
Islamic banking at the crossroads: theory versus practice
}

\author{
Hasan, Zubair
}

International Islamic University of Malaysia

2005

Online at https://mpra.ub.uni-muenchen.de/2821/

MPRA Paper No. 2821, posted 19 Apr 2007 UTC 


\title{
Islamic Banking at the Crossroads: Theory versus Practice
}

\author{
Zubair Hasan
}

This chapter examines the reasons behind a widening gap between the conventional theory and current practice of Islamic banks. 'No risk, no gain' may not be sufficient as a general principle for organising Islamic finance. It is also not always valid to say that Islam is averse to granting a time value for money. The overuse of deferred payment contracts in Islamic finance threatens to violate the juristic principle of sadd al-dhara', that is, controlling the potential avenues for circumvention of the law. Some structural changes in Islamic financial arrangements are suggested to create a balance in the use of profit and loss sharing (PLS) contracts and deferred payment contracts in Islamic banking.

\section{INTRODUCTION}

The ideas relating to Islamic banking and finance were among the first to appear in the writings intended at formalising Islamic economics. They were perhaps put into operation even before theoretical developments on the subject achieved any degree of sophistication. The literature on banking and finance has of late been growing so fast that discussions on other topics in Islamic economics have become few and far between. This may seem understandable as financial factors are becoming increasingly decisive in the processes of creating wealth in modern societies.

A distinctive feature of the recent discussions on Islamic banking has been the growing wedge between its conventional theory and current practice. Interestingly, while the evolution of the theoretical position and its continual support come from what one may call for convenience the Jeddah School, the structural design, instruments and practices of Islamic banking are of late being forged mostly away from the Red Sea, particularly in Malaysia. According to the School, the theoretical foundation of Islamic banking essentially rests, or should rest, on participatory risk-sharing finance - mudārabah and mushārakah. ${ }^{\prime}$ By contrast, practitioners in the area worldwide find these instruments inadequate, and prefer to make deferred contracts with assured fixed incomes the fulcrum of Islamic banking.

A fairly old paper by Abdul Halim on Islamic banking and finance recently 
published (2001) by the Institute of Islamic Understanding of Malaysia (IKIM) puts this divergence into sharp focus. The issue attracted attention at some seminars on Islamic economics and finance held in 2002 in Indonesia and Malaysia, ${ }^{2}$ and in this chapter the implications of the divergence between theory and practice are explored further.

\section{THEORETICAL FOUNDATIONS}

The theoretical edifice for Islamic economics including money and banking started taking shape in undivided India after the 1930s depression. It was an important part of juridical writings aimed at evaluating modern knowledge from an Islamic perspective. The literature, produced mostly in Urdu, was simple with a modern outlook. It reached and became popular with the lower rungs of Muslim society. After the partition of British India in 1947, the dominant part of this endeavour understandably found itself located in Pakistan. The process of Islamising knowledge in economics, as in other areas, expanded and thrived in that country even though contributions from India continued.

As one of the major consequences of the recommendations of the First International Conference on Islamic Economics held at Makkah in 1976, Jeddah eventually emerged as one of the leading centres promoting research in Islamic economics. Many scholars, including some of the pioneers in the discipline, moved from the subcontinent to the two main institutions established in the metropolis: the (International) Centre for Research in Islamic Economics of King Abdulaziz University and the Islamic Research and Training Institute popularly known as the IRTI - of the Islamic Development Bank. In due course, three of the main journals in Islamic economics were almost exclusively devoted to the conducting, promoting and disseminating of research in different areas of Islamic economics. ${ }^{3}$ Their contribution to the growth of literature on the subject is immense and well recognised. No less has been their influence on related writings emanating from other parts of the world.

Initially, these institutions projected an integrated view of Islamic economics in the sense that areas in mainstream economics were not demarcated. Soon, however, the process of category identification began. One major such separation was that of money, banking and finance from the rest of the discipline. This division received recognition in the bifurcation of the Islamic Development Bank's annual prize for contributions to the promotion of Islamic economics into Islamic Economics for one year and Islamic Banking and Finance the next. There may have been reasons for the dichotomy but presumably it did hinder in some measure the balanced growth of the much wider field of Islamic economics. Banking and finance, however important, are no more than subdivisions of the major discipline of economics, secular or Islamic. ${ }^{4}$ 
More important is the fact that the research work stemming from these centres of excellence reveals a common position ascribable to the majority of writers on a number of important issues. There are of course some differences among them, but these often relate to detail, emphasis or form. To illustrate, the School, unlike mainstream economics, shuns in general the idea of scarcity of resources for Islamic dispensation, is not generally receptive to the concept of minimum wages, does not approve of any trade union activity, sees the distribution of income governed by marginal productivity as equitable, usually considers mainstream economics value-free, is opposed to a maximising behaviour on the part of an economic agent, especially the entrepreneur, and is averse to a share for labour in profits of business as a matter of principle. ${ }^{5}$ The situation is no different with respect to the theoretical foundations of Islamic banking. As such then, one may talk loosely of a Jeddah School of Islamic Economics.

Modelling for Islamic banking and finance drew its inspiration for the School, as for others, primarily from the almost unanimous view of the Islamic jurists that there is no difference between the prevalent institution of interest and riba that Islam prohibits. Even though there are many - perhaps more powerful reasons for the prohibition, the School highlighted one in particular: interest is not allowable because it confers a gain on the capital owners free of any riskbearing. This constituted an apparent difference between ribā and the profit from trade that Islam allows. 'No risk, no gain' was, indeed, paraded as an inviolable precept in the area of banking and finance. ${ }^{6}$ The precept implied that it was predetermination of interest without regard to the outcome of the business that kept it free of risk and thus constituted the main reason for its Islamic prohibition. There was little realisation that the implication could conflict, as we shall see, with some other Islamic norms the School upheld.

The precept was suggestive of an answer to the question: if interest were abolished, what must replace it in the financial sector of the economy to induce saving and investment so crucial for creating wealth? The School unequivocally declared that in the absence of interest any reorganisation of banking 'will have to be done' on the basis of partnership, that is, mushärakah or mudārabah contracts. It was also claimed that modern writers on Islamic economics were unanimous on this?

Mushärakah was akin to equity financing of the modern era and could hardly raise a vivid sceptre of Islamic import, nor was it an instrument deriving much glory from the past. In contrast, mudārabah was one pre-Islamic institution that expanded fast in Muslim lands over time and became the most thriving form of business financing by the dawn of the thirteenth century. Naturally, in the modern era of Islamic resurgence, the School saw the theoretical foundations of Islamic banking and finance more in the instrument of mudārabah-based participatory finance, though mushärakah was never ignored. 
The preference for mudärabah provided much food for thought and opened numerous possibilities for the modelling of Islamic banking. The historical model was the first to attract attention. In this puritan model, the owner of capital provided the entire funding to the entrepreneur-operator and had nothing to do with the management of the business. The contract between the parties stipulated a share for the financier in the profits of business while he alone would bear the loss, if any. Usually the contract was for the execution of a specific project. The model suited and worked well in a community where trade was the dominant occupation.

The modern business scenario is radically different. With the rise of the modern corporation working on the principle of limited liability as the dominant form of business organisation, the puritan model of mudārabah lost much of its significance. There were two major points of departure. First, today businesses contributing the bulk of the output in modern economies are founded on a large scale, not for executing short-run piecemeal ventures, but for running an ongoing manufacturing or service activity. Second, financiers usually provide only a part of the total capital. It is in this light that the efficacy of the financing modes for Islamic institutions has to be evaluated. These institutions act as outside financiers providing for a specified period just a fraction of the needed investment. They may also not be willing to eschew a supervisory role to safeguard their interest.

Interestingly, the problems that the puritan design poses under the changed circumstances were anticipated quite early on and discussions on the modus operandi of the mixed sort of mudarabah structures did make their appearance in some of the pioneering works on the subject. In the course of time, they gained currency in the literature as the profit and loss sharing (PLS) models, though investigations into their nature and ramifications were not common or always clear.

In fact, the bank was envisaged as providing money to a firm, the entrepreneur, in participatory contracts on a PLS basis. The loss, as and when it arose, was to be apportioned between the firm and the financier in the same proportion as their respective contributions to the total capital employed in the firm's business. However, the position was a little more complicated in a mixed case on the sharing of profit. A brief explanation may be refreshing.

In a mixed mudärabah model, the bank advances money to a firm on the condition that a pre-agreed proportion, $\sigma^{*}$, of the profit accruing to the money advanced will go to the bank. To illustrate, assume that the outside financier contributes a proportion, $\lambda$, of total capital $K$, and the firm in an accounting period earns a profit $P$, giving the rate of return $r=P / K$. In this case the profit earned on the money advanced by the bank will be $\lambda \mathrm{P}$. Of this amount the bank would get $\sigma^{*} \lambda \mathrm{P}$, that is, a rate of return $\mathrm{r}^{*}=\sigma^{*} \mathrm{r}$ on its investment, if 
transaction costs were ignored. The firm will retain $\left(1-\sigma^{*}\right) \lambda \mathrm{P}$ for providing entrepreneurial services to the bank. This much is clear and undisputed in the literature. The difficulty arises in establishing what guides parties to negotiate for $\sigma^{*}$, that is, what precisely are its determinants, and how will its equilibrium value be arrived at in an economy? A further question is its efficacy for use as an instrument of credit control by a country's central bank. Some scholars have deliberated on these questions and offered solutions, but a consensus has yet to evolve.

The sharing of profit between the bank and the firm is only one half of the story. The other half relates to profit-sharing between the bank and its depositors. To simplify matters, let us assume that the bank has no funds for advancing to business other than those it receives from its customers in deposits (D), that the bank is able to invest D in full, and that there are no transaction costs as before. In this scenario $\lambda \mathrm{K}$ would equal $\mathrm{D}$ and $\sigma^{*} \lambda \mathrm{P}$ would be the profit the bank would share with the depositors in a pre-agreed ratio. If the sharing ratio for the bank were $\Phi$, it would retain $\Phi \sigma^{*} \lambda \mathrm{P}$ of the receipt for entrepreneurial services and distribute the remaining $(1-\Phi) \sigma^{*} \lambda \mathrm{P}$ as profit among the depositors.

Thus Islamic banks would operate on the pattern of what is called in the literature a two-tier mudârabah model. It is sometimes suggested that depositors would receive the same rate of return on their money as the bank would earn on investing it. This equality of ratios proposition is patently untenable even in the absence of transaction costs at both ends. ${ }^{9}$ We have taken above $r^{*}$ as the rate of return the bank earns on $\lambda \mathrm{K}$. Let $\mathrm{R}$ be the rate of return depositors earn on their money with the bank. At the macro level, the banks would receive a mean rate of return on deposit investments as under:

$$
\mathrm{r}^{*}=\sigma^{*} \lambda \mathrm{P} /(\lambda \mathrm{K}=\mathrm{D})
$$

On the other hand, the rate of return $\mathrm{R}$ for depositors would be:

$$
\mathrm{R}=(1-\Phi) \sigma^{*} \lambda \mathrm{P} /(\lambda \mathrm{K}=\mathrm{D})
$$

Since $(1-\Phi)$ is less then one, the rate of return $\mathrm{R}$ would obviously be lower than $r^{*}$ the banks get on their investment. And the banks would eventually earn a net profit equal to $\Phi \sigma^{*} \lambda \mathrm{P}$ for their entrepreneurial services. Who will have a higher rate of return on D in the two-tier mudarabah - banks or depositors - will depend on the value of $\Phi$. The higher $\Phi$ is, the greater will be the rate for the banks as compared with depositors and vice versa.

The literature contains ample demonstration that in a macro frame participatory finance has the potential to give a higher rate of return to both the firms and the banks compared to interest finance, if only because profit rates in the economy tend to be much higher than the rates of interest. In addition, business firms would continue to enjoy the benefits of 'trading on equity' in mudārabah profit-sharing the same way as under interest-bearing finance. ${ }^{10}$ 
Despite the higher profit potential of mudärabah financing in principle, the mode could not make much headway in modern Muslim societies. It did nevertheless emerge as a significant deposit-collecting mechanism with some Islamic financial institutions. For example, muḍārabah companies multiplied fast, especially in Pakistan. But these companies could not find business investment opportunities sufficient to absorb the bulk of the deposits they received. They were thus tempted to make money in the speculative buying and selling of shares traded on the stock markets. The surplus funds accumulating with the Islamic institutions, including banks, led some of the School to believe that the malady could hardly be escaped unless competition from interest-based financing was totally banished: in this respect, Islamic banks could only flourish in a puritan setting! ${ }^{\text {t! }}$

The proposition was neither logical nor practicable. It was tantamount to admitting that the Islamic interest-free system inherently lacked the ability to compete with its mainstream counterpart. What was needed was not despair, but rather the search for the causes behind mudärabah non-performance and a remodelling of the system to meet the changing requirements of the market. It was primarily the failure in this regard that caused lslamic banking and finance to follow the course of least resistance: that is, to take refuge in the indiscreet use of Islamic deferred obligation contracts. ${ }^{12}$

And it is at this juncture that Abdul Halim's paper, alluded to above, challenges the School for its theory of Islamic banking and finance, and defends the almost exclusive reliance of the system at present on assured income contracts. It is a rather lengthy paper with extensive documentation. Broadly, it raises two issues relevant to the context.

First, Halim stresses the undisputed point that the juristic permissibility or otherwise of any basis for financing or a financial contract is determined through the feasibility of its derivation from the sources of Sharíah. But he sees no such juristic feasibility for the 'no risk, no gain' precept. To him, the adherents of the School embrace rather naively the concept of business 'risk' central to capitalism and seek to inject it with an Islamic import through using the Shar'ah's all-pervading notion of al-'adl or justice.

A pre-fixed return like interest in the face of uncertainty about the future outcome of business does not meet the norm, the School argued: justice demands that the provider of capital funds must share the risk with the entrepreneur if he wishes to earn profit." Arguably, this could be accepted as one justification for PLS contracts but in no way constitutes an exclusive principle. One would indeed find the School all at sea in defending other fixed rewards like wages or rent should one choose to stretch the argument to its logical extremes. 
However, Halim offers a different reply emanating from Islamic injunctions. He argues that profit or loss arising from any contract is to be explained from a juristic viewpoint. Relevant to the issue are such Shari'ah norms as effort to earn (al-kasb), placing one's trust in Allah (al-tawakkul), provision of the means for living is derived from Him (al-rizq), and whatever He has ordained - profit or loss - must eventually come to pass (al-qadā wal-qadr). None of these basic elements of faith has ever featured, says Halim, in an explanation of the 'no risk, no gain' axiom of the School. One may add that not every gain is the result of risk-taking or is commensurate with it: profit and risk need not have a one-onone correspondence even in Islamic economics. Profit can rarely be defended as a just reward on the risk-bearing criterion.

Interestingly, one does not come across any valid response in the literature to the points Halim raises. ${ }^{14}$ One must record that his observations do not question per se the permissibility of mudärabah or mushärakah as instruments of Islamic banking and finance. They challenge the School for the principle it regards as underlying the two modes. For Halim, all PLS contracts are equitable from an Islamic viewpoint not because they encompass the capitalist concept of risk but because their legitimacy has been, in the first place, derived from the sources of the Sharitah - in particular the Sunnah. ${ }^{15}$

The rejection of the risk principle leads Halim to his second point - the search for all-embracing norms governing business transactions in Islam. This he finds in what provides the Sharitah basis for an important transaction category: contracts of exchange or 'uqūd al-muawadāt. Quoting extensively from the Qur'ān, learned commentaries and jurists, he explains the difference between interest (al-ribā), and sale (al-bay') in order to establish why Islam rejects the former and upholds the latter. Of the relevant verses discussed, the focus of his attention has been verse 275 from Sürah Al-Baqarah, especially the portion which is translated as: 'But Allah has permitted (that is, pronounced as haläl) albay' and forbidden (that is, pronounced as harām) al-rib $\bar{a}$ '.

Quoting from three of the leading commentaries on the Qur'ān - Ibn Al Arabi, Al Qurtubi and Al Jassas - the author discusses at length the meaning of al-bay ${ }^{\prime}$ and al-riba, and as also the question of their permissibility or otherwise in light of the above verse. The term al-bay' in its generic meaning encompasses all types of contracts of exchange unless forbidden by the Sharī'ah. Al-bay' means any contract of exchange whereby a given quantity of a commodity or service is exchanged for a given quantity of another commodity - including money - or service. ${ }^{16}$ The delivery of the commodity or service on the part of each party to the contract may be simultaneous or one of them - not both - may defer the discharge of his obligation to a future date. Hence the term al-bay' encompasses many types of deferred contracts of exchange, including salam sale (bay'-al salam), sale on order (bay'-al istișnä') and leasing (al-ijärah). 
The term al-ribā as used in the verse in question means what has come to be known in figh as ribä al duyūn, that is, additional consideration imposed by the creditor on the debtor as an inducement for the former to extend the deferred liability period. This is not allowed due to the absence of a compensatory counterpart in real terms. Halim claims that the three commentaries he refers to are unanimous on this interpretation of the verse. ${ }^{17}$

The position of the School also looks untenable on another score, one that is closely related to its 'no risk, no gain' gospel. The School maintains that interest is also prohibited for the reason that Islam does not grant a time value to money. ${ }^{18}$ Some critics argue that not all interest is of the prohibited ribā type and that it is implicitly allowed in a large number of debt-based Islamic transactions. Money is a liquid asset and imposes disability on the creditor to the advantage of the debtor. So it is on the grounds of justice, that is, on the symmetrical treatment of parties, that Islam does allow a time value for money on a selective basis.

We shall examine the basis of this later. Presently, let us return to Halim's argument. Intuitively, one finds in his assertions a cover for the extensive use of deferred exchange contracts in Islamic banking. Malaysia presents an interesting illustration of the use of such contracts. Today, the country is regarded as a pioneer in Islamic banking and finance, and an example for much of the Muslim World to emulate. Some Muslim countries have fully transformed their banking system in accordance with Islamic requirements. However, Malaysia is operating Islamic banking side by side with the conventional system in a rather unique way. ${ }^{19}$ The country has only two exclusive Islamic banks, one of them established as late as 1999. Its main strategy has been to allow the opening of Islamic windows in commercial banks, thus prompting competition for interestfree finance within the conventional system as well. The market share of the Islamic sector - exclusive plus mixed banking - in terms of assets owned is currently around 9.0 per cent. It is planned for this to become 20.0 per cent by the year 2010.

The constituents of the sector in the field are the usual sort of commercial banks, Islamic windows, finance companies, exclusive Islamic units and discount houses. The impact of opening Islamic windows in conventional institutions on the relative position of exclusive interest-free banks is clear from Table 1.1 below.

It is easy to see that the share of exclusive banks went down in all three aggregates - assets, deposits, and financing - more so in the last case, while that of mixed banking, combining conventional operations with Islamic windows, increased. Whether this trend augurs well for Islamic banks is worth considering. At the same time let us also have a look at the trend in the relative role of deferred contracts vis-à-vis PLS financing.

The data produced in Table 1.2 for the three years for which it was available 
Table 1.1: Mixed versus exclusive Islamic banking in Malaysia (\% share)

\begin{tabular}{lcccc}
\hline Category of transactions & \multicolumn{2}{c}{1999} & \multicolumn{2}{c}{2002} \\
\cline { 2 - 5 } & Exclusive & Mixed & Exclusive & Mixed \\
\hline Total Assets & 32.4 & 67.6 & 29.6 & 70.4 \\
Total Deposits & 39.0 & 61.0 & 30.8 & 69.2 \\
Total Financing & 36.7 & 62.3 & 24.9 & 75.1 \\
\hline
\end{tabular}

Source: The percentages are based on data in Bank Negara Annual Reports 2000, Table 4.14, p. 153, and 2002, Table 4.18, p. 156

may not be adequate for indicating a reliable trend in the use of various modes of Islamic finance in Malaysia, but still it is quite revealing: the average share of PLS financing (entries 1 and 2 ) is a meagre 5.6 per cent, the remaining 94.4 per cent coming from deferred liability financing (entries 3 to 8 ). In fact, there is evidence of a falling trend in the share of PLS modes over time in aggregate financing. The trend is found all the more pronounced in the case of Bank Islam Malaysia, the oldest Islamic bank in the country, dating from 1983, whose former chairman was Abdul Halim, the writer cited earlier. The trends in other Islamic banks elsewhere are not dissimilar to those in Malaysia: they too seem to defy the principles of the Jeddah School that favours PLS financing.

Halim is finding more and more supporters for his stance, especially from the West. It is argued, for example in El-Gamal, that to equate ribā with the European notion of usury that raises the mental image of exploitative consumption loans is not appropriate. Much of the ribā used in pre-Islamic Arabia was for commercial and business purposes. Indeed, some controversial fatāwä recently

Table 1.2: Modes of Islamic financing in Malaysia (\% share)

\begin{tabular}{lccc}
\hline Modes of Finance & 2000 & 2001 & $2003^{*}$ \\
\hline 1. Al-Mushārakiah & 1.4 & 0.7 & 0.5 \\
2. Al-Mudārabah & 7.0 & 7.3 & - \\
3. Al-Istișnä & 0.9 & 1.3 & 0.7 \\
4. Al-jjārah & 4.3 & 3.0 & 1.4 \\
5. Al-Muräbahah & - & - & 6.4 \\
6. Al-Bay' bi thaman al-äjil & 48.3 & 49.1 & 47.4 \\
7. Al-ljärah thumma al-bay' & 22.2 & 23.3 & 27.9 \\
8. Other Islamic contracts & 15.9 & 15.3 & 15.7 \\
9. Total & 100.0 & 100.0 & 100.0 \\
\hline
\end{tabular}

* Figures are as at November 2003.

Source: Bank Negara Annual Reports 2001, Table 4.18, and 2002, Table 4.17. 
emanating from Egypt have gone to the extent of holding that conventional bank interest is a share in the profits of growth-inducing investment, and so does not constitute forbidden ribā. ${ }^{20}$

Again, some English translations of the last portion 'lā tažlimūna wa lā tužlamūn' of verse 2:279 dealing with ribä create the impression that the sole objective of prohibition is the avoidance of injustice, that is, the exploitation of the poor debtor by the rich creditor. ${ }^{21}$ However, the meaning of that verse is claimed to be closer to 'if you turn back, then you should collect your principal without inflicting or receiving injustice'. ${ }^{22}$ This implies that both increase and decrease in the principal amount at the time of repayment would be considered unjust.

Finally, the common position in Islamic economics that the School also shares is that Islam does not put a time value on money. The assertion is presently challenged as contradicting statements in all major schools of classical jurisprudence to the effect that 'time has a share in price' (lil zamani hazzun fil thaman). ${ }^{23}$ Indeed, it is this juristic position that constitutes the fulcrum of all deferred obligations on which Islamic financial institutions tend to thrive. This is the basis of cost-plus sale (muräbahah) with deferred receipt of the price, or leasing (ijärah).

Thus seen, ribā meaning addition is not prohibited in all cases. ${ }^{24}$ Ribā alnasi'ah is implicit in deferred contracts. Islamic banks operating in the US are obliged to reveal such implicit rates underlying muräbahah or leasing contracts to their customers. ${ }^{25}$ What Islam doubtlessly prohibits is ribā al-fadl - trading like with like at more than a 1 to 1 ratio - not only in spot transactions but also when extended to future and forward contracts. ${ }^{26}$

\section{CONCLUSIONS}

The foregoing discussion demonstrates that today Islamic banking is at a crossroads. The problem, however, is not the juristic validity of what the Islamic financial institutions can do or are doing: all the instruments of financing listed in Table 1.2 above are equally permissible, and the list is likely to grow in future. Rather it is the reasons advanced to justify their permissibility that can be questioned, and the indiscreet way such financing methods are currently being used. Both have created much avoidable confusion in rationalising the theory for Islamic banking and finance, and have led its practice into suspect tracks. On the theoretical plane, the 'no risk, no gain' principle as the basis for eliminating interest from financial contracts is inadequate, though PLS contracts remain perfectly legitimate.

The profit-risk linkage of the classical era of small owner-operated firms competing in a rather open industry still lingers in the literature. However, the 
concept of risk has undergone a radical change since Frank H. Knight restricted the term to mean uncertainty that could be insured against at a cost. ${ }^{27}$ The remaining uncertainty is a fact of human life like sun or rain: profit or loss is the consequence of opting to bear that uncertainty. Business being a fard kifãyah, obligatory duty, in Islam, ${ }^{28}$ believers must accept the consequence simply as the will of God.

Economists, especially Islamic economists, continue to maintain the old profit-entrepreneur bond in the discipline more as a matter of tradition than reality. That bond has long vanished with the onset of modern corporations. Today it is difficult to identify the entrepreneur in a large multiproduct firm, let alone the functions he performs. ${ }^{29}$ What goes to the entrepreneur, however defined, as profit is seldom possible to defend as equal to the value of his contribution to output: the Islamic criteria for a just reward.

Capitalism justifies interest on the ground that it is the expression of the difference between the present value of goods and their future value. This is the basis of allowing a time value for money, that is, interest. We have already mentioned that Islamic economists do not subscribe to this view. However, time is duly recognised as an element in price. Money provides command over real resources and has an opportunity cost. Islam allows this cost as part of the price. That is what imparts legitimacy to charging higher than cash prices in deferred contracts.

The permissibility of deferred contracts cannot of course be disputed. Nevertheless, the permission cannot perhaps be used without applying checks to safeguard the wider norms and objectives of Islamic law. ${ }^{30}$ The use of deferred contracts in Islamic banking and finance seem to have been carried too far already: it is widely felt that it is time to apply the principle of sadd al-dhara' that closes the potential avenues for circumventing the law. ${ }^{31}$ There is a growing feeling that deferred contracts provide the cover for interest-taking from the back door. ${ }^{32}$

It would be difficult to plead for an exclusive use of deferred contracts to promote Islamic banking. Such use would detract from the ability of these institutions to address more serious issues relating to wealth creation in the Muslim World. The instrument will mainly guide meagre financial resources of the community - as it is presently doing - into consumption channels. A market for venture capital will be hard to develop. To that extent the system is likely to work against capital formation for long-run growth, a basic need of Muslim countries. Most of these countries import consumer goods from abroad. Domestic demand may unwittingly enlarge external markets and aggravate local balance of payment problems. Islamic banks, like their mainstream counterparts, would work for private gain at public expense through distorting social priorities.

The main attraction of deferred contracts is that they bring in assured income at lower risk, thus enabling the Islamic system to compete with conventional 
banks. But the crucial question is how Islamic do the operations remain in the process? Are the banks interested in the promotion of Islamic objectives or norms in the area of finance? Probably they just want to exploit a safer profitmaking opportunity that would not be available to them until existing banking laws were amended to make provision for the opening of Islamic windows. ${ }^{33}$ Some countries such as Indonesia have resisted the temptation to follow the principle of exclusivity in the establishment of Islamic banking institutions. The contribution of windows to the achievements of Islamic banks being much larger than that of exclusive units, many may not be willing to take recent claims of faster growth and greater efficiency for Islamic banks at their face value.

We are not arguing against the use of deferred contracts in Islamic banking, but one can be ignorant of their limitations in achieving the broader Shari'ah objectives. The dismal performance of PLS financing over the years contributed to a rather liberal view of these contracts. A major source of the present discomfiture in Islamic banking is to be sought in the causes of this non-performance and in what could remedy the situation. The malady perhaps lies in PLS' structural mismatching with the goals of Islamic banking.

In principle, commercial banks - as their nomenclature suggests and practice confirms - were conceived for catering to the short-term liquidity needs of trade and commerce. Even when they ventured into long-term commitments their original perspective seldom changed. Keeping liquidity in their operations has ever been their guiding rule. The vast power they enjoy to create credit and the legal framework for their accounts embody this principle. Long- or mediumterm financial needs have invariably called for establishing specialised financial institutions. Industrial banks, agricultural credit societies, housing development corporations, investment houses, import-export banks and refinance corporations are some of the leading examples. It is well to note that some progress on this front is now visible. ${ }^{34}$ Islamic mutual funds and unit trusts are mushrooming, especially in the West, ${ }^{35}$ and much more remains to be done. ${ }^{36}$

In summary, Islamic financial institutions have mostly been designed using the model of commercial banks in terms of their outlook, objectives, procedures, training and modus operandi. They are required, on the other hand, to undertake project financing of long-term risky ventures, and address social aspirations for development and wealth creation. They hardly have the aptitude, support or personnel to do what we expect them to do. ${ }^{37}$ It is like providing shovels and baskets where excavators and trucks were needed for construction.

Opening Islamic windows in Western commercial banks causes an apparent mismatch between the provision of capabilities to them, and what they are expected to achieve. Even if established commercial banks want to enter the field of Islamic finance, it may be preferable for them to establish dedicated Islamic branches. 
Islamic banking in the true sense of the term can rarely meet the vital Shariah objective of raising a strong and prosperous Muslim ummah unless there is a complete break from tradition with reference to goals, sources and uses of funds, and operational methods. The planning authorities of a country, rather than its central bank, must prepare a blueprint for this purpose. Once the development is redirected along appropriate lines, one can hope that PLS schemes and deferred contracts will appropriately supplement one another in the balanced growth and efficient performance of the Islamic financial system.

Finally, Islamic finance, though important, is only a street under construction on a much larger Islamic roadmap. Its ultimate shape, carrying capacity and usefulness will depend on what happens in the bigger picture. Crucial for success in the matter are social conditioning and political will; everything else could then follow.

\section{NOTES}

1. On this point Halim (2001) quotes Siddiqi, Ahmed and Chapra, see pp. 60-1. Other evidence is not lacking.

2. Reference here includes the International Conference on Islamic Economics and Change, Islamic University Yogakarta of Indonesia held on 12-13 October 2002, and the Inauguration Ceremony of the Islamic Finance Services Board, Bank Negara, Kuala Lumpur 3-4 November 2002.

3. The three journals are: Islamic Economic Studies IRTI, King Abdulaziz University; Islamic Economics published by their Centre for Research in Islamic Economics; and Review of Islamic Economics. The Islamic Foundation, Leicester. The School exercises some ideological gatekeeping in each case.

4. Even in mainstream economics with its vast subject coverage, the award of the Nobel Prize does not make this sort of distinction.

5. There may, of course, be differences among individual adherents of the School on a particular point, yet nonetheless there seems to be overall agreement on the issues mentioned.

6. See Chapra (1985) p. 64 and p. 166.

7. See, for example, Siddiqi (1985) p. 9, Chapra (1985) p. 165, and also the supportive foreword by Khurshid Ahmad to the latter's book.

8. For further explanation see Hasan (2002) pp. 42 and 48-9.

9. See Hasan (1989), Section 2: Equality of Ratios Proposition, pp. 86-7.

10. See Hasan (1985) pp. 23-4.

11. See Khan (1995) p. 17 and p. 245.

12. The problem of Islamic financial institutions' surplus funds has now considerably eased for that reason, and not because of an increase in PLS investments.

13. See, for example, Ahmad (1985) p. 4.

14. Proponents of the School now concede the non-exclusive nature of the principle, but still maintain that the: 'PLS principle is the cornerstone of contractual transactions. Moreover, it is the most accepted in the Islamic legal literature.' See Hassan 
(2003) p. 4. Incidentally, the authors provide no argument or documentation in support of their claim.

15. See Halim (2001), p. 66.

16. Here we have departed from Halim's explanation given on p. 25 (item 3 ) of his paper.

17. See also Kamali (1999) p. 102 for his observations on the verse.

18. See, for example, El-Gamal (2001) p. 3.

19. See Wilson (2002), the section: The Pioneering Malaysia, p. 35.

20. See the controversial fatāwā of Sheikh Tantawi (Al Ahram 1989) and the similar fatāwā by Sheikh Wasil (Al-Ittihad 1997)

21. El-Gamal (2001) p. 2.

22. Al-Imam Al-Tabari (1992), vol. 2 pp. 109-10.

23. This contradicts all claims of the School that Islam does not allow a time value for money; for, price is a money expression of value. For fuller references and quotations see, for example, Al-Misri (1997) pp. 39-48.

24. Whether the School calls this addition interest or not is a matter of taste, not of argument.

25. El-Gamal (2001) p. 6.

26. It is for this reason that interest on money loans is not allowed. See El-Gamal (2001) Section 1.3 p. 4 for a brief discussion of the nature of ribā al-fadl. See also Kamali (1999) p. 102.

27. The 'no risk, no gain' precept completely ignores the well-recognised and vital distinction economists make between risk and uncertainty since Knight.

28. Fard kifāya is a social obligation placed on each Muslim and is deemed as performed by all of the community if performed by one or some of them in accordance with the Shariah objective involved.

29. It is time for lslamic economics to take note of changes in business organisation and their impact on the heuristic concept of an entrepreneur and his functions. Who is the entrepreneur and what precisely is his role in a large corporation?

30. For a good discussion on these norms and objectives, see Kamali (1999) Chapter 20 , pp. 395-409.

31. For details, significance and application of the rule, see Kamali (1999) Chapter 16 with translation 'Blocking the Means' pp. 310-20.

32. See Usmani (1998) p. 24.

33. It would be interesting to investigate what the proportion of Muslims is among the users of windows and what proportion Muslims constitute among all bank clients. For it is found that in the recent mushrooming of lslamic equity funds in the US, no more than one out of ten Muslims is using them. It is a question of invoking trust.

34. Failaka Internati nal Inc. www failaka.com lists 100 Islamic bond and equity funds operating worldwide with details about fund name, manager(s), manager location, fund promoter(s), promoter location, inception date, minimum investment, sales load and annual fees. Most of these bonds/funds have heen launched during the last 10 years.

35. Twenty-nine of these are global equity funds, North America has 10, Europe 5. Asia 4, Malaysia 14, emerging markets 12, and the remaining ones are scattered. Malaysia alone has launched 3 lslamic bond (șukük) funds. Out of 100 fund managers, more than 60.0 per cent are located in the US and Europe. Among Muslim countries the 
bulk is shared by Malaysia and Saudi Arabia.

36. Islamic banking has made good progress over the past two decades and managed to stand up to competition from the well-established conventional interest-based institutions. There are claims based on sophisticated econometric models that Islamic banks are more efficient than conventional banks. Such evidence is encouraging but must be treated with caution, not least because the small size of Islamic banks makes comparison with larger conventional banks problematic.

37. Interestingly, this important question is seldom raised in the literature. Rather one comes across explanation, even justification, for the overwhelming use of deferred contracts in Islamic banking: risk aversion was commonly indicated as the reason, but of late earning rates and dividend stability are also being mentioned. For instance, Hassan (2003) includes the two variables among the determinants of Islamic banks' concentration on short-or medium-term finance. But is not the causation in the reverse direction or bidirectional? The authors maintain silence on the point. 